Jurnal Progres Ekonomi Pembangunan (JPEP)

Volume 5, Nomor 2. Tahun 2020

Page: $11-22$

http://ojs.uho.ac.id/index.php/JPEP

\title{
EFEKTIVITAS SIKLUS PENGELOLAAN BARANG MILIK NEGARA STUDI PADA UNIVERSITAS HALU OLEO KENDARI
}

\author{
Desryani Ayulin Inthe \\ Program Ilmu Ekonomi Pascasarjana Universitas Halu Oleo Kendari \\ Email: delin485@gmail.com \\ Arifuddin Mas'ud \\ Fakultas Ekonomi dan Bisnis Universitas Halu Oleo Kendari \\ Email: desi_sia@yahoo.co.id \\ Fajar Saranani \\ Fakultas Ekonomi dan Bisnis Universitas Halu Oleo Kendari \\ Email: fajar.saranani31@gmail.com
}

\begin{abstract}
Abstrak
Penelitian ini bertujuan untuk Untuk mengkaji siklus pengelolaan BMN Negara dalam konteks Perencanaan, pengadaan, penggunaan, pemanfaatan, pengamanan dan pemeliharaan, penilaian, pemusnahan, penghapusan, pemindahtangan, penatausahaan, serta pembinaan dan pengawasan dalam pengelolaan BMN pada Universitas Halu Oleo.

Penelitian ini merupakan penelitian deskriptif kuantitatif dengan sumber data berasal dari wawancara dan kuesioner dan dokumen-dokumen terkait. Teknik pengambilan sampel dalam penelitian ini menggunakan Purposive sampling, dengan teknik pengumpulan data wawancara, kuesioner, observasi dan dokumentasi. Subjek penelitian adalah pejabat, staf pengelola, pengadministrasi Barang Milik Negara, serta operator SIMAK BMN pada Universitas Halu Oleo yang diwakili dengan 17 orang. Analisa data dimulai dengan tahap pengumpulan data, distribusi data, penyajian data dan penarikan kesimpulan.

Hasil penelitian menunjukkan pengelolaan Barang Milik Negara belum sepenuhnya maksimal sesuai dengan peraturan yang berlaku; penatausahaan perlu ditingkatkan agar pencatatan kedalam aplikasi SIMAK BMN dapat dilakukan dengan baik; peningkatan pengawasan terhadap kegiatan pengelolaan BMN agar sesuai dengan Peraturan Pemerintah Nomor 27 tahun 2014.
\end{abstract}

Kata Kunci: Pengelolaan BMN, Siklus Pengelolaan

\begin{abstract}
The research aims to to examine the cycle management of state property management in planning, procuremen, use, utilization, security and maintance, valuation, appraisal, destruction, deletion, alienation, administration, development and controlling in asset management within the Halu Oleo Unversity Kendari.

This research is a quantitative descriptive study with data sources came from interview and questionnaires and with related documents. The sampling technique in the study used purposive sampling. data colection techhnieques with interview, questionnaires, observation, and documentation. The research subjects in this study were officials, management staff, administrators of state property, and SIMAK BMN operator in Halu Oleo University which represented by 17 people. Data analysis begins with the stages of collection, data distribution, data disiplay, and conclusion.

The results of the study showed that management of state property was not fully in accordance with applicable regulation; administration needs to be improved so that recording into SIMAK BMN application can be done properly; increased controlling of BMN management activities to comply with government regulation no. 27 of 2014.
\end{abstract}

Keywords: BMN Management; Management Cycle 
Jurnal Progres Ekonomi Pembangunan (JPEP)

Volume 5, Nomor 2. Tahun 2020

Page: $11-22$

http://ojs.uho.ac.id/index.php/JPEP

\section{PENDAHULUAN}

Indonesia sebagai suatu Negara yang berkembang mempunyai suatu tanggung jawab yang besar dalam mengelola keuangan Negara. Upaya pemerintah Indonesia dalam mengatur keuangan Negara dapat dilihat dengan dikeluarkannya peraturan-peraturan guna mengatur dan mengelola keuangan Negara. Peraturan tentang Keuangan Negara yang diatur dalam Undang-Undang No. 17 tahun 2003 menyatakan bahwa keuangan Negara adalah semua hak dan kewajiban Negara yang dapat dinilai dengan uang serta segala sesuatu baik berupa uang maupun barang yang dapat dijadikan milik Negara berhubungan dengan pelaksanaan hak dan kewajiban tersebut

Barang Milik Negara (BMN) yang merupakan kekayaan Negara yang berasal dari Anggaran Pendapatan dan Belanja Negara (APBD) juga perlu pengelolaan yang efektif dan efisien serta dipertanggungjawabkan sesuai peraturan yang berlaku. Menurut Ravianto (1989), pengertian efektivitas adalah seberapa baik pekerjaan yang dilakukan, sejauh mana orang menghasilkan keluaran sesuai dengan yang diharapkan. Untuk pengelolaan BMN, setiap proses didasarkan pada peraturan yang telah dikeluarkan oleh pemerintah guna setiap pengelolaan BMN dapat dilakukan dengan optimal. Pengelolaan Barang Milik Negara diatur dalam Peraturan Pemerintah nomor 27 tahun 2014 dengan siklus pengelolaan mulai dari perencanaan kebutuhan dan penganggaran, pengadaan, penggunaan, pemanfaatan, pengamanan dan pemeliharaan, penilaian, pemindahtanganan, pemusnahan, penghapusan, penatausahaan, hingga pembinaan pengawasaan dan pengendalian.

Untuk mendukung pengelolaan BMN yang efektif, selain mengatur pengelolaan BMN dalam peraturan pemerintah, pemerintah juga terus melakukan pengembangan salah satunya dalam sistem informasi. Sistem Informasi Manajemen dan Akutansi (SIMAK) BMN merupakan suatu sistem yang dikeluarkan Kementerian Keuangan untuk pengelolaan dan pertanggungjawaban atas BMN yang dikelola.

Setiap lembaga maupun instansi yang mengelola BMN diperhadapkan pada masalah-masalah terkait pengelolaan BMN, dimana pengelolaan BMN harus dilakukan berdasarkan ketentuan yang berlaku serta penyusunan laporan pertanggunganjawaban secara berkala sesuai Standar Akutansi Keuangan (SAK) baik laporan semesteran maupun laporan tahunan. Pengelolaan terhadap BMN mengalami tantangan karena beberapa BMN dapat berpindah secara cepat sehingga terkendala untuk menatausahakan, selain itu proses penilaian dan pengawasan menjadi salah satu tantangan untuk proses pengelolaan $\mathrm{BMN}$.

Mengingat hal tersebut menarik untuk dikaji oleh karena itu telah terdapat studi serupa dengan penelitian ini yang telah dilakukan, antara lain: Lelya fitri ariliana (2018); Anggita Rahadiryanti dan Abdurachman (2012); Monik (2016); Sambudi dan Donald (2011) dan Edy (2015). Penelitian ini bertujuan untuk mengkaji efektivitas siklus pengelolaan Barang Milik Negara (BMN) pada Universitas Halu Oleo Kendari.

\section{KAJIAN LITERATUR}

\section{Manajemen Aset}

Manajemen Aset adalah ilmu dan seni untuk memandu pengelolaan kekayaan yang mencakup proses merencanakan kebutuhan asset, mendapatkan, menginventariskan, melakukan legal audit, menilai, mengoperasikan, memelihara, membaharukan atau menghapus hinggah mengalihkan asset secara efektif dan efisien (A.Gima Sugiama,2013).

Tujuan dari manajamen asset mengacu pada aset yang efektif dan efisien. Menurut Sugiama, bahwa secara umum tujuan manajamen aset adalah untuk pengambilan keputusan yang tepat agar yang dikelola berfungsi secara efekti dan efisien. Efektif adalah pencapaian hasil yang sesuai dengan tujuan sebagaimana yang telah ditetapkan sebelumnya

\section{Pengelolaan Barang Milik Negara}

Peraturan Pemerintah nomor 27 tahun 2014 tentang pengelolaan Barang milik Negara/Daerah mendefinisikan Barang Milik Negara adalah semua barang yang dibeli atau diperoleh atas beban anggaran pendapatan lainnya yang sah. PP 27/2014 menjelaskan Pengelolaan Barang Milik Negara/Daerah dilaksanakan berdasarkan asas fungsional, kepastian hukum, transparansi, efisiensi, akuntabilitas dan kepastian nilai. Pengelolaan BMN dalam Peraturan tersebut meliputi 11 siklus yaitu 
Jurnal Progres Ekonomi Pembangunan (JPEP)

Volume 5, Nomor 2. Tahun 2020

Page: $11-22$

http://ojs.uho.ac.id/index.php/JPEP

perencanaan kebutuhan dan penganggaran, pengadaan, penggunaan, pemanfaatan, pengamanan dan pemeliharaan, penilaian, pemindahtanganan, pemusnahan, penghapusan, penatausahaan, hingga pembinaan pengawasaan dan pengendalian.

Perencanaan kebutuhan dan pengganggaran BMN adalah kegiatan merumuskan rincian kebutuhan Barang Milik Negara untuk menghubungkan pengadaan periode sebelumnya dengan periode berjalan sebagai dasar dalam melakukan perencanaan untuk pencapaian tujuan efisiensi dan efektifitas pengelolaan Barang Milik Negara.perencanaan didasarkan pada standar kebutuhan dan standar barang, juga rencana kebutuhan pelaksanaan tugas.

pengadaan Barang Milik Negara dilaksanakan berdasarkan prinsip efisien, efektif, transparan dan terbuka, bersaing, adil dan akuntabel. Pengadaan dilakukan melalui swakelola maupun pemilihan penyelia barang.

Penggunaan adalah kegiatan yang dilakukan oleh pengguna barang dalam mengelola dan menatusahakan barang milik negara sesuai dengan tugas pokok dan fungsi instansi yang bersangkutan. Penggunaan barang dilakukan dengan melakukan penetapan status penggunaan barang.

Menurut PP 27 tahun 2014 Pemanfaatan merupakan pendayagunaan Barang Milik Negara yang tidak dipergunakan sesuai tugas pokok dan fungsi kementerian Negara/Lembaga/satuan kerja oleh pihak lain dengan tidak mengubah status kepemilikan. Pemanfaatan dilakukan dengan sewa, pinjam pakai, kerjasama pemanfaatan dan bangun serah guna.

Pengamanan adalah kegiatan atau tindakan pengendalian dan penertiban dalam pengelolaan Barang Milik Negara. Tujuan pengamanan adalah untuk menjaga dan melindungi barang sebagai aset negara agar terhindar dari kehilangan, kerusakan, penyalagunaan, penyerobotan dan pengambilalihan atau klaim pihak lain. Pengamanan BMN dapat dilakukan dengan pengamanan administrasi, pengamanan fisik dan pengamanan hukum. Pemeliharaan secara konsepsional dimaksud sebagai rangkaian kegiatan untuk menjaga kondisi dan memperbaiki semua BMN agar selalu dalam keadaaan baik dan siap untuk digunakan secara berdayaguna dan berhasil guna.

Menurut PP 27 tahun 2014 penilaian barang dilakukan dalam rangka penyusunan Neraca pemerintah, pemanfaatan, atau pemindahtangan, dimana dalam proses penilaian barang dalam rnagka penyusunan Neraca pemerintah dilakukan dengan berpedoman pada Standar Akuransi Pemerintah (SAP).

Pemindahtangan menurut PP nomor 27 tahun 2014 adalah pengalihan kepemilikan barang sebagai tindak lanjut dari penghapusan dengan cara dijual, dipertukarkan, dihibahkan atau disertakan sebagai modal pemerintah. Barang Milik Negara yang tidak diperlukan bagi penyelenggaraan tugas pemerintah dapat dipindahtangankan.

Pemusnahan adalah proses tindakan memusnahkan BMN secara fisik dan kegunaan BMN. Menurut PP nomor 27 tahun 2014 pemusnahan dilakukan dalam hal BMN tidak dapat digunakan, tidak dapat dimanfaatkan dan atau tidak dapat dipindahtangankan; serta terdapat alasan lain sesuai dengan ketentuan. Pemusnahan dilakukan dengan persetujuan pengelola barang

Menurut PMK Nomor 83 tahun 2016 , penghapusan adalah tindakan menghapus BMN dari daftar barang dan menerbitkan surat keputusan dari pejabat yang berwenang, dengan tujuan untuk membebaskan pengguna barang dan/atau kuasa pengguna barang dan/atau pengelola barang dari tanggung jawab administrasi dan fisik barang yang berada dalam penguasaannya, dengan memenuhi persyaratan teknis dan ekonomis.

Menurut Permenkeu No. 120/PMK.06/2007, yang dimaksud dengan penatausahaan BMN adalah rangkaian kegiatan yang meliputi pembukuan, inventaris dan pelaporan BMN sesuai dengan ketentuan yang berlaku. Penatausahaan BMN bertujuan untuk mewujudkan tertib administrasi dan mendukung tertib pengelolaan BMN.

pembinaan adalah usaha dan tindakan yang dilakukan secara efektif dan efisien, serta dalam persepektif jangka panjang, baik bersifat perubahan maupun penyempurnaan untuk pengelolaan BMN yang tertib administrasi. Menurut PP nomor 27 tahun 2014 menyebutkan dalam pengawasan dan pengendalian, pengguna barang melakukan pemantauan terhadap penggunaan pemanfaatan, pemindahtangan, penatausahaan, pemeliharaan dan pengamanan BMN yang berada dibawah penguasaannya. 
Jurnal Progres Ekonomi Pembangunan (JPEP)

Volume 5, Nomor 2. Tahun 2020

Page: $11-22$

http://ojs.uho.ac.id/index.php/JPEP

Aplikasi Sistem Informasi Manajamen dan Akuntansi Barang Milik Negara (SIMAK-BMN)

Aplikasi adalah suatu program komputer yang dibuat untuk mengerjakan dan melaksanakan tugas khusus dari pengguna. Kompenen untuk menjalankan suatu aplikasi terdiri dari perangkat keras, perangkat lunak dan pengguna. Menurut Mudiyanto (2015), SIMAK-BMN merupakan Sub sistem dari Sistem Akuntansi selain Sistem Keuangan, yang disajikan untuk meningkatkan pemahaman serta Kontrol yang sistematis, tujuan untuk menghasilkan informasi yang diperlukan sebagai alat pertanggungjawaban pelaksanaan APBN serta pengelolaan dan pengendalian Barang Milik Negara yang dikuasai oleh suatu unit akuntansi barang (Pamungkas dkk.).

\section{Kerangka Konsep}

Kerangka pikir dalam penelitian ini merupakan kajian berdasarkan teori dan peraturan-peraturan yang berlaku tentang pengelolaan Barang Milik Negara. Kerangka pikir dibangun dari rumusan masalah, kajian literatur dan penelitian terdahulu, sehingga dapat dirumuskan kerangka pikir sebagai berikut:

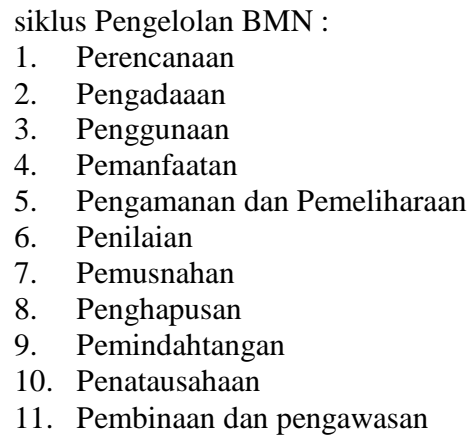

Gambar 1 Kerangka Konsep Penelitian

\section{METODE PENELITIAN}

Penelitan ini dilakukan pada Universitas Halu Oleo dengan waktu penelitian bulan Februari hingga April 2020. Sumber data yang digunakan adalah data primer yang diperoleh dari wawancara dan kuesioner tentang siklus pengelolaan BMN, serta data pendukung lainnya. Populasi adalah keseluruhan staf yang membidangi pengelolaan BMN yang diwakili 17 sampel penelitian, yang terdiri dari 12 respoden dan 5 informan.

Teknis analisis dalam penelitian ini adalah deskriptif presentase. Metode ini digunakan untuk mengkaji variabel yang ada dalam penelitian yaitu bagaimana keefektifan siklus pengelolaan BMN. Pada tahap awal yaitu pengumpulan data, data diperoleh dari kuesioner, wawancara observasi serta dokumentasi. Setelah data dan informasi terkumpul maka dilakukan dilakukan presentase untuk menemukan jawaban dari pertanyaan-pertanyaan yang diajukan. Presentase dilakukan untuk mengukur tahapan pengelolaan Barang Milik Negara apakah telah sesuai dengan peraturan yang berlaku. Setelah tahap presentase data, tahap selanjutnya adalah penyajian data. Penyajian data dapat berupa bentuk tulisan atau kata-kata, gambar, grafik dan table.

\section{HASIL DAN PEMBAHASAN}

Siklus Pengelolaan Barang Milik Negara

Adapun siklus pengelolaan Barang Milik Negara yang dilakukan pada Universitas Halu Oleo Kendari dapat dilihat pada Tabel 1. 
Jurnal Progres Ekonomi Pembangunan (JPEP)

Volume 5, Nomor 2. Tahun 2020

Page: $11-22$

JDCD

http://ojs.uho.ac.id/index.php/JPEP

e-ISSN: 2052-5171

Tabel 1

Hasil Distribusi Jawaban

\begin{tabular}{|c|c|c|c|c|}
\hline No & Keterangan & Sesuai & Tidak Sesuai & Jumlah \\
\hline \multirow[t]{4}{*}{1} & Perencanaan & & & \\
\hline & a. Berdasarkan renstra (Rencana Kebutuhan) & $92 \%$ & $8 \%$ & $100 \%$ \\
\hline & b. Berdasarkan standar barang & $100 \%$ & 0 & $100 \%$ \\
\hline & c. Berdasarkan standar kebutuhan & $100 \%$ & 0 & $100 \%$ \\
\hline \multirow[t]{7}{*}{2} & Pengadaan & & & \\
\hline & a. Berdasarkan prinsip efisien & $100 \%$ & 0 & $100 \%$ \\
\hline & b. Berdasarkan prinsip efektif & $100 \%$ & 0 & $100 \%$ \\
\hline & c. Berdasarkan prinsip transparan & $100 \%$ & 0 & $100 \%$ \\
\hline & d. Berdasarkan prinsip terbuka dan bersaing & $100 \%$ & 0 & $100 \%$ \\
\hline & e. Berdasarkan prinsip adil & $100 \%$ & 0 & $100 \%$ \\
\hline & f. Berdasarkan prinsip akuntable & $100 \%$ & 0 & $100 \%$ \\
\hline \multirow[t]{3}{*}{3} & Penggunaan & & & \\
\hline & a. BMN Telah ditetapkan statusnya & $58 \%$ & $42 \%$ & $100 \%$ \\
\hline & b. telah terdata dalam aplikasi SIMAK BMN & $100 \%$ & 0 & $100 \%$ \\
\hline \multirow[t]{2}{*}{4} & Pemanfaatan & & & \\
\hline & $\begin{array}{l}\text { Pemanfaatan BMN tidak mengganggu tugas dan } \\
\text { fungsi dan tidak mengubah status kepemilikan }\end{array}$ & $100 \%$ & 0 & $100 \%$ \\
\hline \multirow[t]{3}{*}{5} & Pengamanan dan Pemeliharaan & & & \\
\hline & telah dilakukan pengamanan dan pemeliharaan & & & \\
\hline & $\mathrm{BMN}$ & $100 \%$ & 0 & $100 \%$ \\
\hline \multirow[t]{2}{*}{6} & Penilaian & & & \\
\hline & Penilaian BMN sesuai ketentuan yang berlaku & $100 \%$ & 0 & $100 \%$ \\
\hline \multirow[t]{3}{*}{7} & Pemusnahan & & & \\
\hline & $\begin{array}{l}\text { a. BMN dimusnakan tidak dapat lagi digunakan, } \\
\text { dimanfaatkan atau dipindahtangankan } \\
\text { b. Pemusnahan dilakukan denganpersetujuan }\end{array}$ & $100 \%$ & 0 & $100 \%$ \\
\hline & pengelola barang & $100 \%$ & 0 & $100 \%$ \\
\hline \multirow[t]{3}{*}{8} & Penghapusan & & & \\
\hline & $\begin{array}{l}\text { a. penghapusan dilakukan memenuhi persyaratan } \\
\text { teknis dan ekonomis }\end{array}$ & $100 \%$ & 0 & $100 \%$ \\
\hline & $\begin{array}{l}\text { b. Penghapusan dilakukan dengan persetujuan } \\
\text { pengelola barang }\end{array}$ & $100 \%$ & 0 & $100 \%$ \\
\hline \multirow[t]{3}{*}{9} & Pemindahatangan & & & \\
\hline & $\begin{array}{l}\text { a. pemindatanganan dilakukan pada BMN yang } \\
\text { tidak diperlukan dalam penyelenggaraan tugas }\end{array}$ & $100 \%$ & 0 & $100 \%$ \\
\hline & $\begin{array}{l}\text { b. Pemindatangana dilakukan dengan persetujuan } \\
\text { pengelola barang }\end{array}$ & $100 \%$ & 0 & $100 \%$ \\
\hline \multirow[t]{4}{*}{10} & Penatausahaan & & & \\
\hline & a. proses pembukuan & $100 \%$ & 0 & $100 \%$ \\
\hline & b. Proses inventarisasi & $100 \%$ & 0 & $100 \%$ \\
\hline & b. proses pelaporan semesteran dan tahunan & $100 \%$ & 0 & $100 \%$ \\
\hline 11 & $\begin{array}{l}\text { Pembinaan, Pengawasan dan Pengendalian } \\
\text { pembinaan, pengawasan dilakukan sesuai aturan }\end{array}$ & $100 \%$ & 0 & $100 \%$ \\
\hline
\end{tabular}

Sumber: Data Primer diolah, 2020

Dari hasil kuesioner menunjukan bahwa perencanaan telah dilakukan sesuai peraturan, dimana dari tabel diatas menunjukan bahwa $92 \%$ responden menyatakan bahwa perencanaan telah didasarkan pada rencana strategis (renstra), sedangkan terdapat $8 \%$ responden yang mengemukakan hal berbeda dengan penjelasan bahwa masih terdapat perencanaan yang tidak berdasarkan renstra tapi hanya didasarkan pada kebutuhan unit. Artinya mayoritas responden menjawab bahwa pengelolaan BMN dalam siklus perencanaan telah dilakukan sesuai aturan yang berlaku. Hal ini sejalah pendapat Kepala Bagian Barang Milik Negara bahwa pada Universitas Halu Oleo perencanaan dimulai dengan 
Jurnal Progres Ekonomi Pembangunan (JPEP)

Volume 5, Nomor 2. Tahun 2020

Page: $11-22$

http://ojs.uho.ac.id/index.php/JPEP

dasar Rencana Strategis 5 Tahunan dengan memperhatikan kebutuhan untuk melaksanakan tugastugas dan fungsi yang telah ditetapkan dari awal.

"Perencanaan Barang Milik Negara disesuaikan dengan Renstra UHO dan juga melihat kebutuhan masing-masing unit." (Wawancara tanggal 20 April 2020)

Perencanaan yang didasarkan pada kebutuhan dan standar harga dari hasil kuesioner menunjukan presentase $100 \%$ pada kedua indikator tersebut hal menunjukan bahwa perencanaan yang dilakukan pada Universitas Halu Oleo dilakukan dengan berdasarkan pada standar harga dan kebutuhan.

Berdasarkan presentase jawaban untuk siklus pengadaan diatas siklus pengadaan telah dilakukan secara efektif, efisien,transparan, terbuka dan berdaya saing, adil serta akuntable dengan presentase $100 \%$ hal ini menunjukan bahwa seluruh responden menyatakan bahwa proses pengadaan telah dilakukan sesuai ketentuan yaitu berdasarkan PP no. 27 tahun 2014 yaitu dilakukan berdasarkan prinsip efektif, efisien, transparan, tebuka dan berdaya saing, adil serta akuntanble. Hal ini sejalan dengan hasil wawancara yang menyatakan proses pengadaan yang dilakukan pada Universitas halu Oleo melalui pemilihan penyelia barang baik penunjukan langsung maupun melalui lelang.

Berdasarkan table presentase bahwa $42 \%$ menyatakan bahwa proses penggunaan yaitu penetapan status belum dilakukan dan 58\% menyatakan bahwa telah dilakukan penetapan status penggunaan BMN. Artinya bahwa Penetapan status penggunaan BMN pada Universitas Halu oleo belum sepenuhnya dilakukan, hal ini sejalan dengan hasil wawancara Pengelola BMN yang mengemukakan bahwa penetapan status telah dilakukan namun belum terlaksana secara keseluruhan,

"Penetapan status penggunaan BMN telah dilakukan, namun belum semua telah PSP (Penetapan Status Pengguna), ada sementara dalam proses Penetapan status" (wawancara tanggal 28 April 2020)

Berdasarkan hasil distribusi jawaban menunjukan $100 \%$ responden menyatakan bahwa proses pemanfaatan telah dilakukan pada bagian Barang Milik Negara Universitas Halu oleo, dimana pemanfaatan barang tidak menganggu fungsi dan mengubah status kepemilikan BMN. Pemanfaatan yang dilakukan yaitu seperti penyewaan/kerja sama lahan untuk dijadikan kantin dan ATM.

Berdasarkan distribusi jawaban untuk siklus pengamanan dan pemeliharaan pada Barang Milik Negara, $100 \%$ responden menyatakan bahwa pengamanan dan pemeliharaan telah dilakukan. Pengamanan yang dilakukan adalah pengamanan administrasi, pengamanan fisik dan pengamanan hukum.

Berdasarkan distribusi jawaban untuk siklus penilaian menunjukan $100 \%$ responden menyatakan bahwa penilaian BMN pada Universitas Halu Oleo telah dilakukan sesuai ketentuan yang Penilaian terhadap Barang Milik Negara. berdasarkan hasil wawancara dengan kepala bagian BMN menyatakan bahwa Universitas Halu Oleo telah melaksanakan penilaian Barang Milik Negara sesuai ketentuan baik untuk penyusunan neraca, pemanfaatan dan pemindahtangan Barang Milik Negara.

Berdasarkan distribusi jawaban untuk siklus pemusnahan menunjukan $100 \%$ atau seluruh responden menjawab bahwa pemusnahan barang pada Universitas Halu oleo telah dilakukan berdasarkan peraturan bahwa BMN tersebut tidak dapat lagi digunakan, dimanfaatkan dan atau dipindahtangankan, serta telah dimusnakan dengan persetujuan pengelola barang.

Berdasarkan hasil kuisioner menunjukan bahwa penghapusan Barang Milik Negara pada Universitas Halu Oleo telah memenuhi persyaratan teknis dan ekonomis hal ini dtunjukan jawaban responden dengan presentase $100 \%$. Artinya bahwa proses penghapusan BMN pada Universitas Halu oleo telah dilakukan sesuai ketentuan yaitu dilakukan memenuhi persyaratan teknis dan ekonomis. Untuk item penghapusan dilakukan dengan persetujuan pengelolan barang mendapat presentase $100 \%$, dimana responden menyatakan bahwa penghapusan barang telah dilakukan dengan persetujuan pengelola barang.hal ini sejalan dengan hasil wawancara pengelola BMN yang menyebutkan bahwa penghapusan BMN harus dengan persetujuan Kementerian dan dilakukan dengan pertimbangan fisik yaitu secara fisik barang tidak dapat digunakan karena rusak dan tidak ekonomis lagi apabila diadakan perbaikan, karna akan lebih menguntukan bila pengguna barang melakukan penghapusan barang.

Berdasarkan hasil kuesioner seluruh responden yaitu 100\% menyatakan bahwa proses pemindahtangan telah memenuhi ketentuan dimana barang yang dipindahtangankan pada barang yang tidak diperlukan dalam penyelenggaraan tugas dan telah disetujuai pengelola barang, hal ini sejalan 
Jurnal Progres Ekonomi Pembangunan (JPEP)

Volume 5, Nomor 2. Tahun 2020

Page: $11-22$

http://ojs.uho.ac.id/index.php/JPEP

dengan hasil wawancara dengan kepala Bagian Barang Milik Negara yang menyatakan bahwa pemindahtangan dilakukan karena barang tidak diperlukan dalam penyelenggaraan dimana akan lebih efisen bila dipindahtangan karena biaya pemeliharaan yang dikeluarkan lebis besar dari manfaat dan dilakukan dengan mengusulkan kepada pengelola barang.

Berdasarkan hasil kueisoner menunjukan bahwa $100 \%$ responden menyatakan bahwa proses pembukuan, inventarisasi dan pelaporan telah dilakukan oleh Universitas Halu Oleo. Hal ini sejalan dengan hasi observasi dimana Universitas Halu Oleo telah melakukan kegiatan pendataan dan pencatatan barang milik Negara kedalam daftar barang pengguna dengan tujuan agar semua barang milik Negara ada terdata dalam aplikasi aset, pencatatan Barang juga telah dilakukan pada masingmasing unit dengan memuat pencatatan barang dalam Kartu Inventaris Barang (KIB) dan Kartu Inventarisasi Ruangan (KIR).

Berdasarkan hasil kuesioner Universitas Halu Oleo sebagai pengguna barang dengan presentase $100 \%$ menunjukan bahwa telah dilakukan pembinaan dan pengawasan terhadap pengengelolaan Barang Milik Negara, hasil kuesioner sejalan dengan wawancara dengan Kepala Bagian BMN yang menyatakan bahwa telah dilakukan pengawasan BMN melalui pengawas intern melalui satuan Pengawas Internal (SPI) dan juga melalui audit untuk mengawasi pengelolaan BMN pada Universitas Halu Oleo.

\section{Pembahasan \\ Siklus Pengelolaan BMN}

Hasil kuesioner, wawancara dan observasi menunjukan bahwa dalam pengelolaan Barang Milik Negara Universitas Halu Oleo pada masing-masing siklus menunjukan telah dilakukan sesuai dengan ketentuan yaitu berdasarkan pada Peraturan Pemerintah nomor 27 tahun 2014. Hasil penelitian menunjukan setiap tahapan telah dilakukan sesuai ketentuan, namun masih perlu ditingkatkan.

Perencanaan Kebutuhan menurut hasil penelitian menunjukan telah dilakukan sesuai ketentuan yaitu berdasarkan Renstra, standar harga dan standar kebutuhan. Perencanaan dilakukan untuk merincikan kebutuhan Barang Milik Negara kaitannya dengan pengadaan barang pada waktu yang lalu dan keadaan yang ada pada saat ini sebagai dasar dalam pengadaan Barang Milik Negara periode berjalan. Dalam perencanaan barang pada Universitas Halu Oleo yang dibuat dengan memperhatikan kebutuhan, juga memperhatikan ketersedian Barang Milik Negara pada unit-unit yang melakukan permintaan Barang Milik Negara tersebut.

Pada Universitas Halu Oleo proses perencanaan pengadaan Barang Milik Negara, menurut Hasil wawancara dengan Pengelolaan BMN Rektorat dilakukan pada bagian Perencanaan Biro Perencanaan dan Penganggaran,

"Perencanaan dan pengadaan dilakukan oleh Biro Perencanaan dan Penganggaran, dengan data dukung dari Bagian Pengelolaan Barang Milik Negara" (wawancara tanggal 25 April 2020)

Perencanaan yang dilakukan pada bagian perencanaan dimana tetap memperhatikan data dukung dari bagian Badan Milik Negara, data dukung berupa data kesedian barang pada unit, laporan inventarisasi barang yang akan digunakan oleh bagian perencanaan untuk menganalis rencana program kegiatan, yang akan diverifikasi oleh kepala bagian, kemudian dilanjutkan dengan penyusunan Rencana Anggaran Biaya (RAB) dan syarat serta ketentuan lainnya yang akan kemudian akan dilanjutkan untuk diusulkan kepada Biro Perencanaan dan Keuangan, Perencanaan barang pada Universitas Halu Oleo berdasarkan hasil wawancara dan kuisioner dilakukan dengan standarisasi barang dan standarisasi harga yang telah ditetapkan dan dijadikan dasar menyusun rencana kebutuhan yang dituangkan dalam Rencana Kebutuhan Barang Milik Negara (RKBMN). Namun pada beberapa kasus proses perencanaan ditemukan terdapat beberapa unit/fakultas yang melakukan permintaan barang yang tidak berkoordinasi dengan pihak BMN, sehingga bisa berpotensi tidak memperhatikan ketersedian barang, hal ini bertentangan dengan PP nomor 27 tahun 2014 yang menyatakan dalam proses perencanaan harus didasarkan pada standar kebutuhan.

Tahapan Pengadaan Barang pada Universitas Halu Oleo dilakukan dilaksanakan secara lelang/ E-Purchasing dengan menggunakan Layanan Pengadaan Barang dan Jasa secara Elektronik. Dari hasil kuisioner, wawancara dan observasi menunjukan bahwa pada Universitas Halu Oleo pengadaan 
Jurnal Progres Ekonomi Pembangunan (JPEP)

Volume 5, Nomor 2. Tahun 2020

Page: $11-22$

http://ojs.uho.ac.id/index.php/JPEP

barang telah dilakukan sesuai aturan dengan prinsip efisien efektif, transparan, terbuka dan bersaing, adil, serta akuntable. Dimana tahapan pengadaan dilaksanakan dengan membentuk panitia Pengadaan Barang dan Jasa dan dilakukan secara terbuka. pengadaan Barang pada Universitas Halu oleo dilakukan berdasarkan prinsip pengadaan sesuai dengan Peraturan Presiden Nomor 16 tahun 2018 dimana pada proses pengadaan perlu diperhatikan efektif dan efisien dimana menurut hasil wawancara dengan Kepala Bagian BMN, proses pengadaan barang mulai tahun 2009 dilakukan tidak lagi dalam satuan/jumlah yang sedikit namun setiap permintaan pegadaan barang yang telah disetujui dikumpulkan dan diupload untuk proses pengadaannya. Pada proses pengadaan Barang Milik Negara, aplikasi SIMAK BMN hanya berperan memberikan data dukung yang diperlukan dalam proses pengadaan, sedangkan untuk proses pengadaan sendiri dilakukan dalam aplikasi yang berbeda. Pencatatan dalam aplikasi SIMAK BMN dilakukan setelah proses pengadaan selesai dan barang siap untuk diinvetarisasi dalam aplikasi SIMAK BMN dengan kelengkapan berkas yang lengkap. Dalam proses pengadaan dari hasil wawancara dengan Kepala Bagian BMN dan observasi memerlukan beberapa tahapan dan penginputan hingga proses pengadaan selesai dan barang telah diterima dan diperiksa baru kemudian diinput dalam aplikasi SIMAK BMN :

"Proses pelaporan pengadaan barang dilakukan oleh operator belanja barang dan belanja modal dengan menginput dan merekon pada aplikasi bagian keuangan (SAIBA) kemudian diinput pada elektronik, setalah fisik barang datang dan telah diperiksa dan disetujui maka akan diinput pada aplikasi SIMAK BMN dengan kelengkapan berkas.” (Wawancara tanggal 20 April 2020)

Dalam proses pengadaan Universitas Halu Oleo tidak terdapat kendala yang signifikan, hanya beberapa kendala yang bersifat teknis.Pengadaan dalam bentuk jasa konstruksi pada Universitas Halu Oleo dilakukan dengan metode penunjukan langsung dan juga metode E-Purchasing/elang beradasarkan aturan yang berlaku.

Pada tahapan penggunaan Barang Milik Negara dengan melakukan penetapan status menurut hasil penelitian menunjukan telah dilakukan sesuai dengan yang berlaku, namun masih terdapat beberapa BMN yang belum ditetapkan statusnya penggunaannya seperti kendaraan yang terkendala dengan kelengkapan berkas dan beberapa BMN yang masih dalam proses pengajuan penetapan status hal ini sesuai dengan hasil wawancara yang menunjukan pada proses penggunaan Barang Milik Negara masih terdapat beberapa barang yang belum dan atau masih dalam tahapan penetapan status.

Tahapan Pemanfaatan BMN menurut hasil penelitian telah dilakukan dengan tidak menganggu tugas dan fungsi serta tidak mengubah status kepemilikan, dimana proses tersebut sesuai dengan ketentuan PP noor 27 tahun 2014. Pemanfaatan melalui Pinjam pakai dan sewa telah dilaksanakan sesuai ketentuan dimana tidak mengganggu tugas dan fungsi serta tidak mengubah status kepemilikan dan telah dilaksanakan dengan persetujuan pihak terkait dan ditindaklanjuti dengan pembuatan Surat Perjanjian (MOU) sewa menyewa. Jangka waktu penyewaan BMN paling lama 5 (lima) tahun dan dapat diperpanjang kembali. Pemanfaatan Barang Milik Negara yang dilakukan Universitas Halu Oleo telah sesuai dengan Peraturan Pemerintah Nomor 27 tahun 2014, dimana Universitas Halu Oleo sebagai pengguna barang melakukan pemanfaatan BMN dalam penguasaannya dengan persetujuan dari pengelola Barang dan tanpa mengubah status kepemilikan

Pada tahapan pengamanan dan pemeliharaan berdasarkan hasil kuesioner, wawancara dan obsevasi menunjukan telah dilakukan pengamanan namun belum secara maksimal, karna adanya kendala Barang Milik Negara dari berupa kendaraan dinas yang tidak terdapat dokumen pendukungnya seperti bukti kepemilikan. Hasil penelitian melihat adanya kendala dalam pengaman fisik barang yaitu BMN belum memiliki gudang penyimpanan khusus serta pencatatan barang yang berpindah secara cepat seperti kursi dan meja kuliah yang belum secara teratur dicatat dalam inventarisasi ruangan. Pengelola Barang dan pengguna Barang juga bertanggung jawab atas pemeliharaan Barang Milik Negara yang berada dibawah pengawasannya dengan berpedoman pada Daftar Kebutuhan Pemeliharaan Barang. Pemeliharaan barang Universitas Halu Oleo dilakukan menggunakan usulan. Pengamanan dan Pemeliharaan Barang Milik Negara yang dilakukan Universitas Halu Oleo telah sesuai dengan Peraturan Pemerintah Nomor 27 tahun 2014 yaitu pengamanan adminsitrasi, pengamanan fisik dan pengamana hukum, meski terdapat beberapa kendala dalam pengamanan adminsitrasi seperti masih terdapat beberapa barang yang belum terdata sesuai 
Jurnal Progres Ekonomi Pembangunan (JPEP)

Volume 5, Nomor 2. Tahun 2020

Page: $11-22$

http://ojs.uho.ac.id/index.php/JPEP

kondisi barang yang sebenarnya dan pengamanan fisik dimana belum terdapatnya gedung penyimpanan khusus untuk Barang Milik Negara.

Penilai Barang Milik Negara pada Universitas Halu Oleo menurut hasil penelitian telah dilakukan sesuai dengan ketentuan yang berlaku dimana penilaian dilakukan oleh pihak eksternal yaitu Kantor Pelayanan Kekayaan Negara dan Lelang (KPKNL) yang merupakan instansi vertikal Kementrian Keuangan Republik Indonesia. Proses penilaian barang dilakukan melalui usulan dari pengguna barang kemudian membuat daftar usulan barang-barang yang akan dinilai selanjutnya diusulkan untuk dinilai kepada pihak Kantor Pelayanan Kekayaan Negara dan Lelang (KPKNL). Universitas Halu Oleo telah melakukan prosedur penilaian sesuai dengan aturan yang berlaku, untuk penghapusan barang dilakukan setelah disetujui oleh pimpinan, selanjutnya dimohonkan kepada Pihak Kantor Pelayanan Kekayaan Negara dan Lelang (KPKNL) untuk dilakukan penilaian dan penaksiran untuk mengetahui barang yang masih memiliki nilai ekonomis. Hasil penilaian akan menjadi dasar tindaklanjut proses penghapusan melalui pelelangan. Proses penilaian Barang yang dilakukan Universitas Halu Oleo telah memenuhi Peraturan Pemerintah Nomor 27 tahun 2014, dimana dilakukan menurut standar akuntansi pemerintah dan dilakukan oleh penilai pemerintah.

Pada tahapan pemusnahan BMN menurut hasil penelitian menunjukan pemusnahan barang dilakukan untuk BMN yang sudah tidak dapat lagi digunakan, dimanfaatkan dan dipindahtangankan. pemusnahan Barang Milik Negara dilakukan untuk Barang Milik Negara seperti kursi kuliah yang telah dalam kondisi rusak (tidak layak pakai) dan telah dilakukan lelang namun tidak mempunyai nilai. Kendala yang ditemui untuk pemusnahan Barang Milik Negara adalah pada prosedur yang dianggap rumit dan membutuhkan waktu yang lama. Pemusnahan yang dilakukan Universitas Halu Oleo ini telah sesuai dengan Peraturan Pemerintah nomor 27 tahun 2014 serta Peraturan Menteri Keuangan RI Nomor 83/PM.06/2016 tentang Tata Cara Pelaksanaan Pemusnahan dan Penghapusan Barang Milik Negara.

Pada tahapan penghapusan menurut hasil penelitian telah dilakukan dengan pertimbangan secara teknis dan ekonomis dimana barang tidak dapat lagi digunakan akibat moderisasi hal ini terjadi pada beberapa software/aplikasi dan hardware seperti komputer. Penghapusan barang pada Universitas Halu Oleo juga berdasarkan hasil wawancara dengan Kepala Bagian Barang Milik Negara juga menyatakan telah mengacu pada syarat ekonomis dimana barang yang dihapuskan akan lebih menguntungkan bagi Negara, karena adanya biaya operasional dan pemeliharaan yang jauh lebih besar daripada manfaat yang diperoleh. Penghapusan barang pada Universitas Halu Oleo telah dilakukan sesuai aturan, namun terdapat beberapa kendala menurut hasil wawancara dengan pengelola Barang Milik Negara menjelaskan bahwa penghapusan beberapa barang masih terkendala dengan persuratan/atau kelengkapan berkas khususnya pada Barang Milik Negara seperti Motor dinas yang telah rusak namun belum mempunyai kelengkapan berkas untuk dilakukan penghapusan, hal ini juga disebabkan karena masih rendahnya pengamanan barang secara hukum, dimana beberapa BMN belum memiliki bukti kepemilikan.

Untuk tahapan pemindahtangan menurut hasil penelitian menunjukan bahwa pemindahtangan telah dilakukann sesuai ketentuan yang berlaku dimana BMN yang dipindahtangankan tidak diperlukan untuk penyelenggaraan tugas dan telah disetujui oleh pengelola barang. Proses pemindahtangan melalui penjualan prosesnya akan dilakukan bekerja sama dengan kantor Pelayanan Kekayaan Negara dan Lelang (KPKNL). Pemindatangan pada Universitas Halu Oleo dilakukan secara penjualan/lelang yaitu berupa barang persediaan seperti komputer, untuk aset tetap sendiri menurut Kepala Bagian BMN belum ada dilakukan. Pada proses pemindahtangan, aplikasi SIMAK BMN hanya sebatas pada laporan hasil pemindatangan dan data dukung lainnya yang diperlukan untuk proses pemindatanganan Barang Milik Negara, sehingga tidak terdapat kendala besar dalam proses pemindatangan. Kendala yang ditemui pada proses pemindatangan berupa proses pelaporan pada aplikasi SIMAK BMN yang harus menunggu semua kelengkapan berkas pemindatangan telah terkumpul.

Pada tahapan Penatausahaan Barang Milik Negara pada Universitas Halu Oleo berdasarkan hasil penelitian sudah dilakukan berdasarkan PP nomor 27 tahun 2014, kendati belum dilakukan secara maksimal dan perlu ditingkatkan terutama pada penginventarisasian barang dan pendataan 
Jurnal Progres Ekonomi Pembangunan (JPEP)

Volume 5, Nomor 2. Tahun 2020

Page: $11-22$

http://ojs.uho.ac.id/index.php/JPEP

kondisi barang. Penatausahaan telah dilakukan melui pembukuan, inventarisasi dan pelaporan semesteran. hasil observasi menunjukan penggolongan dan kodefikasi barang belum sepenuhnya dilakukan oleh pengelola BMN pada Universitas Halu Oleo, Penatausahaan BMN dilakukan melalui aplikasi Sistem Informasi Manajemen dan Akuntansi (SIMAK BMN), dengan adanya aplikasi SIMAK BMN proses penatausahaan menjadi lebih akutanble dan informatif, serta sesuai dengan aturan yang berlaku.

Pada tahapan pembinaan, pengawasan dan pengendalian menurut hasil penelitian menunjukan Universitas Halu Oleo telah melakukan tahapan pembinaan dengan melakukan pelatihan kepada pengelola BMN dan juga melakukan pengawasan dan pengendalian pengelolaan BMN dengan bantuan Satuan Pengawasan Internal.

Dari hasil penelitian menunjukan bahwa pengelolaan BMN telah disesuaikan dengan peraturan namun belum sepenuhnya maksimal. Pada tahapan penggunaan yaitu penetapan status BMN dan penatausahaan masih perlu ditingkatan, pada tahapan penetapan status masih terkendala dengan berkas kelengkapan berkas BMN, hal selaras juga diungkapkan pada penelitian Lelya Safitri (2018) yang menunjukan kendala pada tahapan penggunaan yaitu penetapan status pada universitas Sebelas Maret terkendala berkas yang diperlukan. Tahapan penatausahaan masih terkendala dengan beberapa BMN yang belum dibukukan dan diiventarisasi dengan berkala sehingga perlu ditingkatkan, hal serupa juga ditunjukan oleh penilitian yang dilakukan Ivan Setiadi, dkk (2019) yang menunjukan bahwa penatausahaan di Lingkungan Kementerian Agama Kabupaten Donggala belum efektif karena adanya pencatatan yang tidak didukung keterangan, pembaruan data dan informasi aset yang tidak dilakukan dengan berkala. Dampaknya dari penatausahaan yang tidak dilakukan dengan maksimal adalah kondisi barang dalam laporan tidak sesuai dengan kondisi yang sebenarnya.

\section{KESIMPULAN DAN SARAN \\ Kesimpulan}

Dalam pengelolaan barang Milik Negara pada Universitas Halu Oleo telah dilakukan dengan pedoman Peraturan Pemerintah Nomor 27 tahun 2014. Implementasi Peraturan ini dalam upaya meningkatkan efektifitas pengelolaan BMN yaitu perencanaan, pengadaan, penggunaan, pemanfaatan, pengamanan dan pemeliharaan, penilaian, pemindahtangan, pemusnahan, penghapusan, penatausahaan dan pembinaaan, pengawasan dan pengendalian. Secara umum 11 proses pengelolaan Barang Milik Negara secara umum telah dilaksanakan sesuai ketentuan, namun persentase kesesuaian belum maksimal sebagaimana peraturan Pemerintah Nomor 27 tahun 2014, hal ini disebabkan pada beberapa tahapan yang mengalami kendala sehingga belum dilaksanakan sesuai ketentuan, antara lain Pada beberapa usul perencanaan, dalam penetapan status penggunaan barang, dalam proses pengamanan dan pemeliharaan, belum terdapatnya gedung penyimpanan BMN yang mengakibatkan kendala dalam pengamanan Barang Milik Negara secara fisik, serta pada pencatatan dan pendataan barang belum dilakukan dengan tertib.

\section{Saran}

Saran dari hasil penelitian ini yaitu: (1) Bagi peneliti yang berminat untuk mengkaji serta melakukan penelitian ulang, disarankan untuk lebih memperdalam dan mengembangkan penelitian ini, baik mengembangkan konsep teori maupun mengembangkan indikator atau dapat mengkaji lebih dalam beberapa proses pengelolaan BMN; (2) Peneliti selanjutnya dapat mengembangkan penelitian ini dengan memodifikasi variabel untuk mendapatkan hasil yang lebih baik, seperti membandingkan kendala yang dihadapi instansi lain dalam pengelolaan BMN, kemudia dapat menambahkan solusi pengelolaan BMN dan (3) Bagi Universitas Halu Oleo, kiranya terus meningkatkan keefektifan proses pengelolaan Barang Milik Negara, terutama pada proses penatausahaan dan penetapan status Barang Milik Negara. 
Jurnal Progres Ekonomi Pembangunan (JPEP)

Volume 5, Nomor 2. Tahun 2020

Page: $11-22$

http://ojs.uho.ac.id/index.php/JPEP

\section{DAFTAR PUSTAKA}

2018. Laporan Kinerja Universitas Halu Oleo. Kendari

Adha, Rahmawati \& Azhar. 2014. Pengaruh Akuntablitas, Ketidakpastianlingkungan dan Komitmen Pimpinan terhadap Penerapan Tranparansi Pelaporan Keuangan. Jurnal akuntansi pemerintah.

Afandi, M. N., and A. Sulastri. 2012. Peranan sistem informasi manajemen akuntansi barang milik Negara dalam menunjang akuntabilitas pengelolaan barang milik negara (studi kasus di pusat penelitian geoteknologi lipi Bandung). Jurnal Ilmu Administrasi Volume IX, Nomor 3. hal. 290-308.

Ariliana F Leyla. 2018. Pengelolaan Aset Berbasis Sistem Informasi Manajemen dan Akutansi Barang Milik Negara (SIMAK-BMN) di lingkungan Badan Layanan Umum (BLU) Universitas Sebelas Maret Surakarta.

Donald A. Rumokoy. 2011. Implementasi Pengelolaan Barang Milik Negara di Pengadilan Tinggi Agama Manado.

Dwi Pratiwi Sari. 2012. Analisis Pengelolaan Barang Milik Negara di bidang peralatan khusus penanggulangan keamanan berkadar tinggi, studi kasus pada Mako Korps Brimob POLRI Kelapa 2. Universitas Indonesia.

D.W Monik Ajeng Puspitoarum. 2016. Analisis Pengelolaan Barang Milik Negara pada Badan Pusat Statistik Kota Makassar. Vol 4 No.4. Hal 229-241

Hariyono, A. 2017. Modul Prinsip Teknik Manajamen Kekayaan Negara. Tangerang: Badan Pendidikan dan Pelatihan Keuangan Pusdiklat Keuangan Umum.

Inthe A Desryani. 2020. Efektivitas Pengelolaan Barang Milik Negara Berbasis Aplikasi Sistem Informasi Akuntansi dan Manajemen (SIMAK BMN) studi pada Universitas Halu Oleo Kendari. Tesis. Program Pascasarjana Universitas Halu Oleo Kendari.

Kuncoro, Mudrajat. 2007. Metode Kuantitatif Teori dan Aplikasi Untuk Bisnis dan Ekonomi. Yogyakarta: UPP STIM YKPN;

Nasruddin, Edy. 2015. Efektivitas Sistem Informasi Manajemen dan Akuntasi Barang Milik Negara (SIMAK BMN) terhadap pengelolaan aset negara. Jurnal Ilmiah Akuntansi Universitas Jember. Vol 13 No.2. Hal 45-52;

Nawawi, Hadari. 2003. Manajamen Sumber Daya Manusia Untuk bisnis yang komperatif. Yogyakarta: Universitas Press Yogyakarta.

Pamungkas, Bambang, dkk. 2011. Evaluasi Aplikasi Sistem Informasi Manajamen Akuntansi Barang Milik Negara (SIMAK-BMN) Kaitannya dalam Pencatatan Nilai Aset Tetap Pemerintah Studi Kasus pada Pusat Penelitian dan Pengembangan Tanaman Pangan Bogor. Jurnal Penelitian. Bogor.

Peraturan Menteri Keuangan Republik Indonesia Nomor 171/PMK.05/2007 Tentang Sistem Akuntansi dan Pelaporan Keuangan Pemerintah Pusat.

Peraturan Menteri Keuangan Republik Indonesia Nomor 83/PMK.06/2016 Tentang Tata Cara Pelaksanaan Pemusnaan dan Penghapusan Barang Milik negara.

Peraturan Menteri Keuangan Republik Indonesia Nomor 96/PMK.06/2007 Tentang Tata Cara Pelaksanaan Penggunaan, Pemanfaatan, Penghapusan dan Pemindahtangan Barang Milik Negara.

Peraturan Menteri Keuangan Republik Indonesia Nomor 120/PMK.06/2007 Tentang Penatausahaan Barang Milik Negara.

Peraturan Menteri Keuangan Republik Indonesia Nomor 29/ PMK.06/2010 Tentang Penggolongan dan Kodefikasi Barang Milik Negara.

Peraturan Pemerintah Republik Indonesia Nomor 27 Tahun 2014 Tentang Pengelolaan Barang Milik Negara /Daerah.

Peraturan Pemerintah Republik Indonesia Nomor 6 Tahun 2006 Tentang Pengelolaan Barang Milik Negara/Daerah.

Peraturan Pemerintah Republik Indonesia Nomor 71 Tahun 2010 Tentang Standar Akuntansi Pemerintah. 
Jurnal Progres Ekonomi Pembangunan (JPEP)

Volume 5, Nomor 2. Tahun 2020

Page: $11-22$

http://ojs.uho.ac.id/index.php/JPEP

Peraturan Presiden Republik Indonesia Nomor 54 Tahun 2010 Tentang Pengadaan Barang/Jasa Pemerintah.

Rahardiyanti,A.K dan Edi Abdurrachman. 2012. Evaluasi Efektivitas Sistem Informasi Manajamen dan Akutansi Barang Milik Negara (SIMAK BMN) di Departemen Kebudayaan dan Parawisata Republik Indonesia. Jurnal of Applied Finance and Accounting Vol. 5 No. (1). Hal 110-128.

Saragih, Risma. 2017. Efektivitas Kebijakan Penatausahaan Barang Milik Negara di Sekolah Tinggi Penyuluhan Pertanian Medan. Jurnal Administrasi Publik Vol. 7 No. (1). Hal 77-93;

Setiadi Ivand, dkk. 2019. Analisis Penatusahaan BMN di Lingkungan Kementrian Agama Kabupaten Donggala. E Jurnal Katalogis. Vol 6. No.4. Hal 10-20.

Siregar, Doli D. 2004. Manajamen Aset. Jakarta: Gramedia Pustaka Utama.

Undang-Undang Nomor 1 Tahun 2004 Tentang Perbendaharaan Negara.

Undang-Undang Republik Indonesia Nomor 17 Tahun 2003 Tentang Keuangan Negara.

Wijaya, Nadirsyah dan Darwanis. 2013. Faktor-Faktor Yang Mempengaruhi Kepuasaan Pengguna Terhadap Aplikasi Sistem Akutansi Keuangan dan Sistem Informasi Manajamen dan Akutansi BMN Pada Lembaga Kejakasaan RI wilayah kejaksaan Tinggi Aceh. Jurnal Akutansi Pascasarjana Universitas Syiah Kuala. Vol 3 No. 1. Hal 21-28. 